\title{
Sri Baduga Museum as a Source For Social Learning in The Material of People Existence in Hindu - Buddhism Period
}

\author{
Bunga Rosyana ${ }^{1}$, Dadang Sundawa ${ }^{2}$, Mamat Ruhimat ${ }^{3}$ \\ Social Science Education, Faculty of Social Science Education, \\ Universitas Pendidikan Indonesia, Bandung, Indonesia
}

\begin{abstract}
This research is based on the social studies learning process that has been happening so far, limited by formal classrooms, educators only use textbooks as the only source of social studies learning, in order to achieve social studies learning objectives, it is necessary to choose learning resources that are in accordance with the material. Sri Baduga Museum is conceptually relevant to be used as a source of social studies learning in the subject of community life during the Hindu-Buddhist period. The purpose of this study is to find out the collections in the Sri Baduga museum that can support the material of community life during the Hindu-Buddha, to find out the activities which are conducted by students in utilizing Sri Baduga Museum collection that supports the subject of community life during the HinduBuddha period, to find out the optimization Sri Baduga Museum as a source of social studies learning in the subject of community life during the Hindu-Buddhist period, and to find out the obstacles of the use of Sri Baduga Museum as a source of social studies learning in the subject of community life during the Hindu-Buddhist period. Data collection will be conducted by observation, interviews and documentation. This study reveals that; First, there are collections that support the subject of community life in the Hindu-Buddhist period such as, replicas of Inscriptions, replicas of Arca, replicas of Candi. Second, the activities which are conducted by students are tour activities which is going around from the first floor to the third floor, watching movies, recording important things and taking photos as documentation. Third, optimization which are conducted by the staff are providing good facilities, as well as adding collections, revitalizing the Classic Period Room. Fourth, obstacles which are experienced in terms of funding.
\end{abstract}

Keywords: Learning Resources, Museum of Sri Baduga Social Science

Correspondence. rosyanabunga@gmail.com

Article History. Received January 2019, Received in revised March 2019, Accepted June 2019

(C2019. International Journal Pedagogy of Social Studies. Department of Social Studies Education

\section{A. INTRODUCTION}

The choice of learning resources is one of the important criteria in the process of social studies learning. Jarolimek (in Komalasari, 2010, p. 113) educators need to use learning resources in learning process with the following reasons:

a. Not all students learn in the same way, different media can be adapted to students who have different learning style.

b. Reading coverage between different students requires learning resources.

c. Each media has strengths and limitations in how to deliver learning materials. There are many different learning resources.

Komalasari, (in Yusuf, 2018, p.2) that 'the components in learning consist of goals, materials, methods, media, and evaluations. Learning that can be utilized in social studies learning processes such as museums, buildings, temples, or other historical heritage objects that can be used as learning resources. Through objects that are used as learning resources, it is possible for students to understand material more easily.

The social studies learning process does not only take place in classrooms at school but also takes place in the community, with the advancement of technology in the field of education. Textbooks are not the only learning resources in social studies learning, social studies learning must be able to answer the challenges from time to time. One of learning resources that can be used in learning of social studies is the use of museums, as part of the community that can be picked by educators for learning activities outside the classroom, because of the exhibition collections and museum dioramas which can help improve 
students' understanding of Social studies subject that are taught in the classroom, especially a subject which is relating to the history of the development of human and environment.

In accordance with the understanding of the museum formulated by ICOM (in Sulaiman, 1990, pp. 100-107) stated that "museum is a permanent institution, does not seek profit in serving the community, and in its development is open for public, which functions to preserve, communicate, and exhibiting human proof and environmental goods for the purpose of study, education and pleasure." Museum is a place to store valuable objects that are given an upkeep and protection, and also it is an institution that does not seek profit, as an effort to preserve heritage works that have historical value.

Sri Baduga Museum is conceptually relevant being used as a resource of social studies learning in $7^{\text {th }}$ grade (First grade in Junior High School in Indonesia), because there are various collections that support social studies learning topics, especially in the subject of community life during the Hindu-Buddha, various collections such as reliefs, inscriptions, sculptures, statues, various royal maps, which are the objects of the Hindu-Buddhist period inherited in the museum exhibition, so that by visiting the museum, students are not only learning about theory, but also seeing the evidence of historical developments in the Hindu-Buddhist period directly.

Based on data, the number of visitors of the Sri Baduga Museum, from January to December 2018, the classification of visitors shows that visitors from TK (Kindergarten) is 2,305 visitors, while from elementary schools is 25,688 visitors, then from junior high school is 36,339 visitors, and from high school is 13,688 visitors, while from college students is 2,343 visitors, and from the public is 5,262 visitors, and from Wisman is 84 visitors. From the data, junior high school is the most frequent visitors, it shows that Sri Baduga Museum is relevant for social studies learning subject at the junior high school. The existence of Sri Baduga Museum is one of media to preserve cultural objects and also useful for the world of education.

The focuses of this study are firstly, to find out the collections in Sri Baduga Museum that could support the subject of community life during the Hindu-Buddhist period. Secondly, to find out the activities of students in utilizing the
Sri Baduga Museum collection that supports the subject of community life during the HinduBuddhist period. Thirdly, to find out the efforts to optimize Sri Baduga Museum as the resource of social studies learning in the subject of community life during the Hindu-Buddhist period. Fourthly, to find out the various obstacles and solutions in the use of the Sri Baduga Museum as a resource of social studies learning in the subject of community life during the Hindu-Buddhist period.

\section{B. METHOD}

This study uses a qualitative approach, and used as a research procedure to analyze a phenomenon or social situation within a certain scope, and also it uses a natural setting that the results of analysis are in the form of a narrative or picture. Sukmadinata (2012, p. 60) suggests "qualitative research is a study that is shown to describe and analyze phenomena, events, social activities, attitudes, beliefs, perceptions, human thoughts in individuals or in groups".

The method that is used in this study is descriptive method. Descriptive research is a method that is based on real conditions that occur in the field which are then described and analyzed by researchers. Mardalis (2003, p. 26) states "descriptive research aims to describe the conditions that currently apply. There is an effort to describe, record, analyze and interpret the conditions that currently occur or exist."

The type of research that is used in this study is case study. Emzir (2016, p. 20) suggests "case study is a qualitative research that seeks to find meaning, investigate processes, and gain deep understanding of individuals, groups or situations."

\section{Data Collection \\ Observation}

Observation has an aim which is to observe the object of research directly. "Observation is a technique of data collection by conducting research thoroughly, as well as systematic recording" (Gunawan, 2014, p. 143). The researcher will observe various activities in the museum in accordance to the museum as a resource of social studies learning in the subject of Indonesian people during the Hindu-Buddhist period. 


\section{Interview}

The interview is a question and answer process conducted by two parties. Interviews in qualitative research are profound because it requires to explore information holistically and clearly from informants. Gunawan (2014, p. 16) states "interview is a conversation directed at a particular problem and a process of oral question and answer in which two people or more physically face to face". Through interview techniques, the researcher will obtain information that is the focus of this study.

\section{Documentation Study}

In qualitative research, the documentation study is a tool for using observation and interview methods. Documentation study is conducted by collecting, analyzing documents, and records that is relevantly important, so that it can provide data to solve problems in a research. Bungin (2008, p. 121) suggests "documentation technique is one method of collecting data used in social research to trace historical data". Documentation study in this study are intended to enrich and complement the information and data.

\section{Data Analyses}

Data analysis techniques include the process of analyzing, processing and interpreting data that has been obtained. Data analysis is conducted by reducing and presenting data, and drawing conclusions. The validity of the data in this study uses triangulation techniques. Triangulation is a technique of data checking by comparing data that have been obtained from one source to another with a different approach. It has a purpose to check or compare research data that have been obtained from one source to another with a different approach.

\section{Results and Discussion}

1. The Collections of Sri Baduga Meseum that Could Support the Subject of Community Life during Hindu-Buddhist period.

There is compatibility with a number of collections that are available in the Sri Baduga Museum, with social study learning $7^{\text {th }}$ grade textbooks issued by the Ministry of Education and Culture, which located on the outside of The Museum (museum yard) in the presence of Tugu replicas. There is information on the collection that explains the name of the collection object, which is Prasasti Tugu, then a brief history of the object collection which is a relic of the Tarumanegara Kingdom, written in Sanskrit and Pallawa letters. As well as the translation of the contents of the Prasasti Tugu in Indonesian and English. The collection is quite adequate for the process of utilizing the museum as a learning resource for social studies. Students can read the information that is contained in the collection, which will strengthen students' understanding of the subject of community life during the HinduBuddhist period.

Then there is a replica of the Borobudur Temple, which is stored in the collection storage warehouse. It will be on display for visitors when there are several events. The Borobudur Temple replica collection is relevant to the subject of community life during the Hindu-Buddha period, because the collection is in accordance with the material in the student's textbooks. In a textbook, it is explained that one of the buildings used by Buddhism is Borobudur Temple. However, the replica collection of Borobudur Temple is inadequate for the process of utilizing the museum as a resource of social studies learning since not all visitors can see the replica collection of Borobudur Temple.

In the collection storage section, there is also a replica collection of Prambanan Temple, which is stored in the collection storage warehouse. It will be on display for visitors when there are several events. Prambanan Temple replica collection is relevant to the subject of community life during the Hindu-Buddha period, because the collection is in accordance with the material in the student's textbooks. In the textbook, it is explained that one of the buildings used by Hinduism is Prambanan Temple. Nevertheless, the Prambanan Temple Replica collection is inadequate for the process of utilizing the museum as a resource of social studies because not all visitors can see the replica collection of Prambanan Temple.

In the central part of the museum, there are various Arca replicas which are stored in the central part of the museum and referred to the classical period room. In this room, there is an exhibition of various Arca collections, such as Arca Brahma replicas, Shiva Arca replicas, Arca Padmapani replicas, Arca Parvati replicas, Arca of the Mahadeva Shiva replica, and replica of the Buddha's Head Arca. There is information on each collection of Arca replicas that explains the 
name of a collection object, then a brief history of object collections. With the existence of several collections of Arca, it is quite adequate for the process of utilizing the museum as a learning resource for social studies.

Then there is a replica of the Buddha's head statue, which is stored on the first floor in the central part of the Sri Baduga Museum. There is information on collection objects, such as the place where the Buddha's statue was found in Batu Jaya, Karawang. In addition, there is information about the function of the Buddha's head statue, which is used as a religious service in Buddhist ceremonies. With the replica of the Buddha's Head of Arca, it is quite adequate for the process of utilizing the museum as a social science learning resource.

\section{Student Activities in Utilizing the Sri Baduga Museum Collection that Supports the Subject of Community Life in the Hindu-Buddhist Period}

Various activities which is done by students such as, tour activities from the first floor to the third floor, tour activities in Sri Baduga Museum can be guided by several guides who are ready to explain chronologically each collection of relics during the HinduBuddhist period. Other activities which is done by students around Sri Baduga Museum, students were freed to explore the museum. It seems most of the students read the information on each collection of relics of the HinduBuddhist period, and there are some students who write information that is considered important for learning activities. Some of the students on their visit brought worksheets assigned by social studies teachers which must be filled with an information from several collections of heritage objects during the HinduBuddhist period, so that during their visit to the museum, several students worked on assignments that is assigned during their visit to the Sri Baduga Museum.

Various teaching exhibition and digital multimedia are the main attraction for students. Most of the students are very enthusiastic when trying to use a variety of exhibition and multimedia media provided in the Sri Baduga Museum. Not only provides a variety of teaching exhibition and digital multimedia media, but Sri Baduga Museum also provides an auditorium, as a place to showcase several films or performances to the students, so that some students during their visit are given time to watch film screenings on history, or a brief explanation of people's lives during the HinduBuddhist period provided in the auditorium.

In each tour activities to the Sri Baduga Museum, there are some students who document their visit by taking pictures and making videos with various collections of relics during the Hindu-Buddha period, then taking pictures with their friends, and there are some students who document each collection provided in Sri Baduga Museum. After the tour activities in the museum is complete, students are expected to be able to obtain some benefits of visiting Sri Baduga museum which is used as a resource of social studies learning.

\section{Efforts to optimize the Sri Baduga Museum as an IPS Learning Resource in the Material of Community Life in the Hindu-Buddhist Period}

The optimization of the museum is conducted in accordance with a particular mission in developing the museum as a learning resource. For this reason, the staff of the museum are always trying to increase the number of collections, and add teaching exhibition and multimedia especially in the classical period room, and repair some damaged collections, with room revitalization to make it easier for visitors to observe and enjoy it.

Various optimization of treatments for collections of Hindu-Buddhist cultural relics conducted by the museum staff, such as the treatment on the entire collection of relics of the Hindu-Buddhist period that available at the museum, $90 \%$ conducted preventive maintenance. Furthermore, there is remedial treatment to restore the damaged collection of Hindu-Buddhist relics back to its original form, revitalizing the classical period room, there are several of plans to improve visual exhibition to be used again. There are also the documentation and conservation section so that the existing collection is maintained and well maintained and structured in the demonstration room.

The next optimization activity is providing a guide as people who act as seekers, stores, managers and message presenters. The information delivered by the guide is in the form of teachings or in the form of ideas, facts, teachings, values and data regarding people's 
lives during the Hindu-Buddhist period. Optimization activities conducted by social studies teachers in utilizing museums as a learning resource, especially in the subject of community life during the Hindu-Buddhist period, using outdoor learning strategies by bringing students directly to Sri Baduga Museum.

\section{Obstacles and Solutions for Utilizing Sri Baduga Museum as a Learning Resource of Social Study in the Subject of Community Life in the Hindu-Buddhist Period}

Some obstacles in making Sri Baduga Museum as a learning resource in the subject of community life during the Hindu-Buddhist period is the difficulty of adding archaeological collections to add Classic period collections or repairing the damaged collections in Classic Time Room that have been damaged for a long time, hampered by funding that has an effect of unable to repair damaged collection objects, and hampered revitalization of the classic period room due to lack of funding.

The solution made by the museum staff to the lack of funding in repairing damaged facilities and infrastructure, by embracing IT communities from several universities that work as volunteers, to be able to assist in terms of improving facilities and infrastructure. Solution in terms of the lack of facilities for disabled visitors by providing some workers to help for visitors with disabilities. Another solution is to be able to optimize the function of the museum as a learning resource, at this time the museum is trying to build relationships with several travel parties, to be able to make the museum as a tourist destination.

The constraints felt by social studies teachers, in utilizing Sri Baduga Museum as a resource of social studies learning is in determining the scheduled departure to the museum. Another obstacle in determining the transportation to get to the museum which need to use funds. This is in line with the opinions of Dick and Carey (in Komalasari, 2010, p. 126) suggest "several benchmarks that need to be considered in choosing learning resources are (a) availability of resources; (b) availability of funds, personnel and facilities; (c) flexibility, practicality and endurance (age) of learning resources; and (d) the effectiveness of learning resources for a long time."
Solution for the difficulty of choosing the right time to visit Sri Baduga Museum, several groups that were in a study tour to Sri Baduga Museum, during their visit were not only for social studies subjects, but there were also several subjects assigned to visit Sri Baduga Museum, so that it will be effective when visiting the museum, and choose to visit on holidays. Solution to the funds or costs needed to be able to visit Sri Baduga Museum is all of the students who will do a study tour in Sri Baduga Museum have to buy the ticket on their own, including transportation cost. Meanwhile, for the students who cannot effort to buy their ticket on their own will have a subsidy from their school so that they still can join school activities such as visiting Sri Baduga Museum.

\section{CONCLUSION}

First, the collection at Sri Baduga Museum that supports the subject of community life during the Hindu-Buddhist period is on the first floor. The collection is exhibited on the outside of the museum (museum yard), there is a replica of the Tugu Prasasti. In the collection warehouse there are replicas of Borobudur and Prambanan Temples, and in the central room of the museum which is Classic period room, there is a collection of Arca Replicas. The collection objects are in accordance with the material contained in the social study $7^{\text {th }}$ grade textbook issued by the Ministry of Education and Culture. So, with the collection of these objects, it can strengthen students' understanding of the subject community life during the Hindu-Buddhist period.

Second, the activities of students in utilizing Sri Baduga Museum collection that supports the subject of community life during the Hindu-Buddhist period, by going around all floors, from the first floor to the third floor. After the tour activities, students are given time to enter the auditorium, to watch several films about history. Then, students are given a free time to be able to explore all types of collections in Sri Baduga Museum. In this activity, some students write information that is considered important for their learning activities, and some students on their visits bring worksheets to be done during their visit to Sri Baduga Museum. The next activity is that some students use various teaching exhibition and digital multimedia provided at Sri Baduga Museum. In each tour activities in Sri Baduga Museum, there 
are several students who documented their visit by taking pictures and making videos with various collections of relics from the HinduBuddha period, or making fun with friends.

Third, the optimization efforts conducted by the staff of Sri Baduga Museum, in making the museum as a learning resource of social studies in the subject of community life during the Hindu-Buddha period is by providing good facilities, then preventive activities, remedial (treatment) activities, and there are plans to increase the number of collections, exhibition media, and multimedia especially in the Classic period room, and repair some damaged collections, by doing a more specific revitalization of the room, to make it easier for visitors to observe and enjoy each collection. Then the availability of guides as people who act as seekers, stores, managers and message presenters. Furthermore, optimization conducted by social studies teachers in making the museum as a learning resource in the subject of community life during the Hindu-Buddhist period is by applying outdoor learning strategies by bringing students directly to visit Sri Baduga Museum.

Fourth, the obstacles faced by the museum in utilizing Sri Baduga Museum as a resource of social studies learning in the subject of community life during the Hindu-Buddhist period is lack of funding. The solution made by the museum is by embracing IT communities from several universities that work as volunteers, to be able to assist in improving facilities and infrastructure. The obstacles experienced by social studies teachers in making Sri Baduga Museum is also lack of fund. The solution is each student paying their ticket on their own to visit
Sri Baduga Museum. Except for students with low economic conditions, they will get subsidies from the school.

\section{REFERENCES}

Bungin, Burhan. (2010). Penelitian Kuliatitatif: Komunikasi, Ekonomi, Kebijakan Publik, Dan Ilmu Sosial Lainnya. Jakarta: Kencana.

Emzir. (2016). Metodologi Penelitian Kualitatif. Jakarta: Rajawali Pers.

Gunawan, Imam. (2013). Metode Penelitian Kualitatif, Teori \& Praktik. Jakarta: Bumi Aksara.

Gunawan, Imam. (2014). Metode Penelitian Kualitatif, Teori \& Praktik. Jakarta: Bumi Aksara.

Komalasari, K. (2010). Pembelajaran Kontekstual: Konsep dan Aplikasi. Bandung: Reflika Aditama.

Mardalis. (2003). Metode Penelitian (Suatu Pendekatan Proposal). Jakarta: Bumi Aksara.

Sukmadinata, Nana Syaodih. (2012). Metode Penelitian Pendidikan. Bandung: PT. Remaja Rosdakarya.

Sulaiman, Jusuf. (1990). Permuseuman Indonesia. Ensiklopedia Nasional Indonesia. Jilid 13. Jakarta: Cipta Adi Pustaka.

Yusuf, Riyan. (2018). Utilization of "Bocah Pejuang" TV Show of Trans TV to Improve Social Intelligence in Student on Social Studies Learning. International Journal Pedagogy of Social Studies, 3, 18. 